\title{
PEMBELAJARAN FISIKA DENGAN PENDEKATAN PROBLEM BASED LEARNING (PBL) MENGGUNAKAN MODUL DAN BULETIN DITINJAU DARI KEMAMPUAN VERBAL DAN MOTIVASI BERPRESTASI SISWA
}

\author{
Siti Fatimah ${ }^{1}$, Sarwanto $^{2}$, Nonoh Siti Aminah ${ }^{3}$ \\ ${ }^{1}$ Program Studi Pendidikan Sains Program Pascasarjana \\ Universitas Sebelas Maret, 57126, Indonesia \\ stfatimah89@gmail.com \\ ${ }^{2}$ Program Studi Pendidikan Sains Program Pascasarjana \\ Universitas Sebelas Maret, 57126, Indonesia \\ sar1to@yahoo.com \\ ${ }^{3}$ Program Studi Pendidikan Sains Program Pascasarjana \\ Universitas Sebelas Maret, 57126, Indonesia \\ nonoh_nst@yahoo.com
}

\begin{abstract}
Abstrak
Tujuan penelitian ini adalah untuk mengetahui pengaruh pembelajaran fisika dengan PBL menggunakan modul dan buletin, kemampuan verbal, serta motivasi berprestasi terhadap prestasi belajar. Metode penelitian ini menggunakan penelitian eksperimen. Populasi penelitian adalah seluruh siswa kelas XI IPA di SMA Negeri 1 Sidareja tahun pelajaran 2012/2013 sebanyak 4 kelas. Sampel penelitian ditentukan dengan teknik cluster random sampling sebanyak 3 kelas. Kelas eksperimen 1 menggunakan modul, kelas eksperimen 2 menggunakan buletin, dan kelas eksperimen 3 menggunakan pendekatan konvensional. Teknik pengumpulan data menggunakan metode tes untuk mendapatkan data prestasi kognitif produk dan kemampuan verbal siswa, metode angket untuk mendapatkan informasi prestasi kognitif proses, prestasi afektif, dan motivasi berprestasi siswa. Uji hipotesis penelitian menggunakan uji Kruskall-Wallis. Hasil penelitian dapat disimpulkan: (1) pendekatan PBL menggunakan modul dan buletin memiliki pengaruh lebih baik daripada pendekatan konvensional terhadap prestasi produk dan proses; (2) tidak ada pengaruh antara pendekatan PBL menggunakan modul dan buletin dengan kemampuan verbal terhadap prestasi belajar; (3) ada pengaruh pendekatan PBL menggunakan modul dan buletin dengan motivasi berprestasi terhadap prestasi kognitif proses dan afektif; (4) pendekatan PBL menggunakan modul dan buletin memiliki interaksi yang lebih baik dengan kemampuan verbal dan motivasi berprestasi kategori tinggi dan rendah daripada pendekatan konvensional.
\end{abstract}

Kata kunci: pembelajaran fisika, pendekatan PBL, modul, buletin

\section{Pendahuluan}

Peraturan Pemerintah Republik Indonesia Nomor 19 Tahun 2005 dalam Undang-Undang Republik Indonesia Nomor 20 tahun 2003 tentang Standar Nasional Pendidikan pasal 1 menjelaskan bahwa tujuan Standar Nasional Pendidikan adalah menjamin mutu pendidikan nasional dalam rangka mencerdaskan kehidupan bangsa dan membentuk watak serta peradaban bangsa yang bermartabat. Dalam mewujudkan Standar Nasional Pendidikan tersebut, pemerintah selalu berusaha untuk dapat memperbaiki dan mengembangkan sistem pendidikan di Indonesia ke arah yang lebih baik. Salah satu usaha pemerintah dalam memperbaiki dan mengembangkan sistem pendidikan adalah menyusun Kurikulum Tingkat Satuan Pendidikan (KTSP). KTSP diharapkan dapat mengembangkan pembelajaran ke arah yang 
lebih baik, yaitu dapat merubah paradigma pembelajaran dari teacher centered menjadi student centered.

Kurikulum mata pelajaran IPA/fisika peserta didik diharapkan dapat melakukan pengamatan, berpikir kritis, berpikir kreatif, dan memiliki rasa ingin tahu. Hal ini sesuai dengan hakikat dari ilmu IPA yaitu produk sains, proses sains, dan sikap ilmiah sains. Namun, hasil observasi di SMA Negeri 1 Sidareja Cilacap menunjukkan bahwa pada proses pembelajaran masih kurang menjadikan siswa sebagai pusat dalam pembelajaran fisika, belum memperhatikan karakteristik ilmu IPA/sains.

Menurut Meilani Kasim (2009) hasil survei Political and Economic Risk Consultant (PERC), kualitas pendidikan di Indonesia berada pada urutan ke-12 dari 12 negara di Asia. Posisi Indonesia berada di bawah Vietnam. Data yang dilaporkan The World Economic Forum Swedia (2000), Indonesia memiliki daya saing yang rendah, yaitu hanya menduduki urutan ke-37 dari 57 negara yang disurvei di dunia. Rendahnya prestasi belajar di Indonesia juga dialami oleh SMA Negeri 1 Sidareja, Cilacap. Ditinjau dari hasil rata-rata kelulusan mata pelajaran fisika di SMA Negeri 1 Sidareja pada jangka waktu lima tahun terakhir dari tahun 2007/2008 yaitu 7,37; tahun 2008/2009 yaitu 8,36 ; tahun $2009 / 2010$ yaitu 7,19 ; tahun 2010/2011 yaitu 8,77; dan 2011/2012 yaitu 6,94. Meskipun masih sesuai dengan harapan pemerintah yaitu rata-rata kelulusan untuk mata pelajaran IPA adalah 5,5, namun perlu ditingkatkan agar nilai IPA khususnya fisika menjadi meningkat. Meskipun ditinjau dari kognitif produk, SMA Negeri 1 Sidareja memiliki nilai yang cukup bagus, namun ketika dibandingkan dengan pendidikan di dunia, pendidikan di Indonesia khususnya di SMA Negeri 1 Sidareja masih perlu ditingkatkan dalam hal proses dan sikap ilmiah sehingga akan terbentuk hakikat dari ilmu IPA secara menyeluruh. Dengan diperhatikan keseluruhan aspek penilaian, mulai dari produk, proses, dan sikap siswa, maka diharapkan prestasi siswa akan lebih meningkat.

Pelaksanaan pembelajaran sains/IPA, khsusunya fisika dapat dilakukan dengan berbagai pendekatan, metode, dan menggunakan media pembelajaran. Beberapa pendekatan, metode, dan media yang dapat digunakan oleh guru dalam pembelajaran yang berorientasi pada proses adalah Contextual Teaching and Learning (CTL), Problem Based Learning (PBL), Problem Solving, eksperimen, inkuiri, video, modul, dan buletin agar pembelajaran dapat bermakna sehingga tidak hanya kognitif produk yang dinilai. Namun pada kenyataannya, pendekatan dan metode serta media pembelajaran belum banyak dioptimalkan dan diterapkan pada pembelajaran fisika.

Materi gerak getaran merupakan salah satu konsep fisika yang abstrak, sehingga diperlukan cara pembelajaran yang tepat agar dapat dipahami oleh siswa, salah satunya adalah menghubungkan konsep tersebut dengan kehidupan sehari-hari. Namun, pada kenyataannya, pada proses pembelajaran masih kurang dalam menghubungkan konsep gerak getaran dengan kehidupan sehari-hari.

Selain IQ dan sikap ilmiah siswa, kemampuan verbal dan motivasi berprestasi memiliki pengaruh terhadap prestasi belajar. Namun, pada proses pembelajaran masih kurang memperhatikan faktor-faktor tersebut dalam proses pembelajaran.

Penelitian Jane Oakhill, dkk (2011) menunjukkan bahwa siswa yang memiliki kemampuan verbal dan numerik diprediksi lebih dapat memahami bacaan dengan baik, sedangkan kemampuan mengingat spasial menunjukkan kurang baik dalam memahami bacaan. Penelitian Rachel Mamlok dan Naaman (2011) menghasilkan bahwa motiviasi adalah variabel yang penting dalam mendorong kinerja keterampilan serta membangun pemahaman konsep yang bermakna.

Gagne dalam Winkel (1996: 323) untuk menemukan kondisi-kondisi peserta didik yang belajar informasi verbal, peserta didik harus memiliki motivasi yang tinggi, mampu menggunakan bentuk organisasi yang baik sehingga dapat menguasai teknik-teknik yang sesuai, memiliki ketajaman berpikir dalam menemukan konsep-konsep, memiliki kemampuan untuk membahasakan makna yang ada di dalam konsep agar dapat disimpan dalam memori dalam bentuk yang bermakna. Menurut Barlia dalam Rachel Mamlock dan Naaman 
(2011) menyatakan bahwa motiviasi adalah variabel yang penting dalam mendorong kinerja keterampilan serta membangun pemahaman konsep yang bermakna.

Ausubel dalam Ratna Wilis Dahar (1989: 112) menyatakan bahwa "belajar bermakna merupakan suatu proses mengaitkan informasi baru pada konsep-konsep relevan yang terdapat dalam strukutur kognitif seseorang". Dari pernyataan tersebut jelas bahwa dalam pembelajaran perlu dilakukan proses sains, yaitu dengan melibatkan siswa untuk belajar sehingga pembelajaran akan lebih bermakna bagi siswa.

Menurut Wee, Kek dalam Taufiq Amir (2010: 32) mengatakan bahwa pendekatan PBL menitikberatkan pada permasalahanpermasalahan yang ada untuk merangsang siswa dan memicu siswa untuk menjalankan pembelajaran dengan baik dalam menemukan sebuah konsep/gagasan. Keunggulan pendekatan PBL dibandingkan dengan pendekatan lain salah satunya adalah PBL membangun pemikiran yang metakognitif dan konstruktif.

Keunggulan bahan ajar modul adalah modul dapat dijadikan sebagai bahan ajar mandiri yang berfungsi untuk meningkatkan kemampuan peserta didik untuk belajar sendiri. Hasil penelitian John D. Pantis (2009) menjelaskan tentang pembuatan/desain modul pendidikan yang bertujuan untuk meningkatkan kesadaran dan sikap siswa tentang spesies yang terancam punah. Hasil dari penelitian ini menunjukkan dampak yang signifikan terhadap tingkat kognitif dan sikap siswa.

Keunggulan dari buletin adalah menggunakan bahasa yang lugas dan komunikatif, lebih menekankan pada isi buletin yang sifatnya menarik pembaca karena didesain untuk dapat menarik perhatian. Namun, pada kenyataanya pada proses pembelajaran belum menggunakan modul/buletin berbasis PBL.

Berdasarkan latar belakang di atas, pembelajaran fisika dengan pendekatan PBL menggunakan modul dan buletin ditinjau dari kemampuan verbal dan motivasi berprestasi diharapkan dapat mendorong siswa dalam berpikir mandiri, dan dapat memberikan pemahaman konsep yang dihubungkan dengan konteks kehidupan sehari-hari sehingga siswa dapat mengerjakan bentuk-bentuk latihan soal yang disajikan dalam modul/buletin yang berbentuk kontekstual.

\section{Metode Penelitian}

Populasi dalam penelitian adalah siswa SMAN 1 Sidareja Tahun Ajaran 2012/2013 sebanyak empat kelas. Teknik pengambilan sampel dengan Cluster Random Sampling, yaitu diambil secara acak dengan diambil tiga kelas. Desain penelitian menggunakan desain faktorial $3 \times 2 \times 2$.

Instrumen yang digunakan berupa instrumen pelaksaan pembelajaran berupa silabus, RPP, LKS, modul, buletin dan instrumen pengambilan data berupa tes, lembar angket, lembar observasi, dan lembar interview. Teknik tes untuk mengukur prestasi kognitif produk dan kemampuan verbal dengan menggunakan tes pilihan ganda dengan satu jawaban benar. Teknik non-tes berupa lembar angket, lembar observasi, lembar interview, dan dokumentasi. Lembar angket digunakan untuk mengukur prestasi kognitif proses, afektif, dan motivasi berprestasi siswa. Lembar observasi digunakan untuk menilai prestasi kognitif proses dan afektif pada saat pembelajaran, sedangkan interview dilakukan untuk mendapatkan informasi tambahan untuk menguatkan hasil penelitian. Dokumentasi berupa foto dan video saat pembelajaran berlangsung. Uji validitas intrumen dibagi menjadi dua, yaitu validitas isi dan validitas konstruk yang dilakukan oleh ahli sebelum diujicobakan ke lapangan.

Teknik analisa data menggunakan uji Kruskall Wallis dengan program PASW dan uji lanjut Kruskall Wallis menggunakan uji MannWhitney $U$ dengan ketentuan jika $p$-value $<5 \%$, maka hipotesis awal ditolak, artinya ada pengaruh pembelajaran PBL melalui modul dan buletin, kemampuan verbal, motivasi berprestasi terhadap prestasi belajar. 


\section{Hasil Penelitian dan Pembahasan}

Tabel 1.1. Ringkasan Hasil Uji Kruskall-Wallis

\begin{tabular}{ccccc}
\hline No. & $\begin{array}{c}\text { Sumber } \\
\text { Variansi }\end{array}$ & $\begin{array}{c}p \text {-value } \\
\text { prestasi } \\
\text { kognitif } \\
\text { produk }\end{array}$ & $\begin{array}{c}p \text {-value } \\
\text { prestasi } \\
\text { kognitif } \\
\text { Proses }\end{array}$ & $\begin{array}{c}p \text {-value } \\
\text { prestasi } \\
\text { afektif }\end{array}$ \\
\hline 1 & $\mathrm{~A}$ & 0,000 & 0,049 & 0,381 \\
2 & $\mathrm{~B}$ & 0,065 & 0,499 & 0,065 \\
3 & $\mathrm{C}$ & 0,746 & 0,000 & 0,000 \\
4 & $\mathrm{AB}$ & 0,000 & 0,129 & 0,186 \\
5 & $\mathrm{AC}$ & 0,004 & 0,000 & 0,000 \\
6 & $\mathrm{BC}$ & 0,277 & 0,004 & 0,000 \\
7 & $\mathrm{ABC}$ & 0,003 & 0,003 & 0,000 \\
\hline
\end{tabular}

Tabel 1.1 menjelaskan ringkasan hasil Uji Kruskall-Wallis, dengan A adalah pengaruh PBL menggunakan media pembelajaran terhadap prestasi, B adalah pengaruh PBL menggunakan media pembelajaran dengan kemampuan verbal terhadap prestasi, $\mathrm{C}$ adalah pengaruh media pembelajaran dengan motivasi berprestasi, $A B$ adalah Interaksi antara media dengan kemampuan verbal, AC adalah interaksi antara media dengan motivasi berprestasi, $\mathrm{BC}$ adalah interaksi antara kemampuan verbal dengan motivasi berprestasi, ABC adalah interaksi PBL menggunakan media, kemampuan verbal, dan motivasi berprestasi.

Ada pengaruh pembelajaran fisika dengan pendekatan Problem Based Learning (PBL) menggunakan modul dan buletin terhadap prestasi kognitif produk dan proses siswa. Menurut Savin dan Badin; Moust, Bouhuijs, Schmidt dalam Taufiq Amir (2010: 23) menyebutkan bahwa PBL berbeda dengan metode ceramah. PBL menekankan pada informasi tertulis yang berupa masalah dan diberikan sebelum kelas dimulai. Sehingga akan mendorong siswa untuk berpikir menemukan sebuah konsep. Dengan mendorong siswa berpikir, siswa akan lebih mengingat dan memahami konsep yang ditemukan.

Modul berbasis PBL memiliki keunggulan dibandingkan dengan buletin. Modul dalam penelitian ini, selain berbasis PBL, merangkum materi semua materi gerak getaran secara sistematis menjadi sebuah bahan ajar. Sehingga siswa dapat belajar secara mandiri untuk mempelajari materi selanjutnya sebelum pembelajaran dimulai, sedangkan buletin diberikan tahap demi tahap dalam setiap pembelajaran sehingga siswa hanya dapat belajar materi gerak getaran menggunakan buletin pada saat pembelajaran akan dimulai. Modul dalam penelitian ini memuat latihanlatihan soal yang lebih banyak daripada buletin dan terdapat bentuk tes mandiri untuk dikerjakan setelah pembelajaran selesai, sedangkan bentuk soal dalam buletin hanya memuat beberapa bentuk latihan soal yang dikerjakan pada waktu pembelajaran akan selesai. Sehingga siswa yang menggunakan modul akan lebih memiliki banyak kesempatan untuk mengerjakan bentukbentuk latihan soal daripada buletin.

Modul berbasis PBL selain memiliki kunggulan seperti di atas, modul ini disusun untuk melatih siswa dalam belajar mandiri. Dalam pembuatan tes mandiri ditambahkan keterangan bahwa jika kemampuan siswa menjawab soal benar mencapai $\geq 80 \%$, maka siswa dapat melanjutkan materi selanjutnya, namun jika kurang, maka siswa diharapkan mempelajari kembali materi yang belum dipahami sebelum melanjutkan materi selanjutnya. Selain hal tersebut, dalam modul dilengkapi dengan glosarium yaitu untuk mengulas konsep-konsep yang telah dipelajari dan tips-tips yang dapat berfungsi untuk menambah wawasan yang terkait dengan materi gerak getaran.

Tidak ada pengaruh pembelajaran fisika dengan PBL menggunakan modul dan buletin terhadap prestasi afektif. Berdasarkan Taufiq Amir (2010: 28) menyebutkan bahwa dengan PBL dapat membangun kerja tim, kepemimpinan, dan keterampilan sosial. Penelitian yang dilakukan Andrew Walker menyimpulkan bahwa dengan adanya integrasi antara video dengan PBL diyakini akan meningkatkan aktivitas siswa dalam pembelajaran apabila pendidik dapat menggunakan dan terbiasa menggunakan teknologi. Jadi, dengan adanya PBL akan membantu siswa untuk aktif dalam setiap pembelajaran. Namun, untuk menumbuhkan keterampilan sosial yang baik harus memiliki kerja sama yang bagus antar sesama anggota kelompok, memahami perannya dalam kelompok, menerima pandangan/pendapat teman kelompok. Dengan demikian, akan terjalin kerja tim yang bagus.

Berdasarkan hasil observasi, hanya beberapa siswa saja yang dapat aktif, yaitu 
siswa yang dipandang pandai dalam satu kelompok tersebut, baik siswa yang menggunakan modul atau buletin sehingga dengan demikian kurang adanya kerja sama yang bagus antar masing-masing anggota kelompok. Berdasarkan Uji Lanjut MannWhitney $U$ menghasilkan bahwa media modul dan buletin memiliki pengaruh lebih baik daripada pendekatan konvensional dalam prestasi produk dan proses.

Tidak ada pengaruh pembelajaran fisika dengan PBL menggunakan modul dan buletin dengan kemampuan verbal kategori tinggi dan rendah terhadap prestasi belajar siswa, Menurut Gagne dalam Winkel (1996: 323) untuk menemukan kondisi-kondisi peserta didik yang belajar informasi verbal, peserta didik harus memiliki motivasi yang tinggi, mampu menggunakan bentuk organisasi yang baik sehingga dapat menguasai teknik-teknik yang sesuai, memiliki ketajaman berpikir dalam menemukan konsep-konsep, memiliki kemampuan untuk membahasakan makna yang ada di dalam konsep agar dapat disimpan dalam memori dalam bentuk yang bermakna. Menurut Jane Oakill (2011) menyebutkan bahwa kemampuan verbal yang terdiri dari bahasa/katakata dan rentang angka dipengaruhi oleh kemampuan membaca dan kemampuan memahami kata-kata. Meninjau pernyataan tersebut, tidak adanya interkasi antara pembelajaran PBL dengan kemampuan verbal terhadap prestasi dikarenakan dalam penelitian di lapangan, belum menganalisis adanya motivasi dalam diri siswa sebelum pembelajaran, belum memberikan latihanlatihan soal untuk pengukuran kemampuan verbal sehingga siswa masih cenderung bingung dalam menyelesaikan tes akhir, belum semua siswa memiliki kemampuan membahasakan konsep dan disimpan dalam memori panjang meskipun telah dibentuk kelompok diskusi.

Tidak ada pengaruh pembelajaran fisika dengan PBL menggunakan modul dan buletin dengan motivasi berprestasi kategori tinggi dan rendah terhadap prestasi kognitif produk siswa, namun ada pengaruh terhadap prestasi kognitif proses dan prestasi afektif siswa. Menurut McClelland dan Atkinson dalam Wasty
Soemanto (2003: 354) motivasi berprestasi adalah kecenderungan seseorang berjuang untuk mencapai sukses atau memilih suatu kegiatan yang berorientasi untuk tujuan sukses atau gagal. Siswa yang memiliki motivasi untuk mencapai prestasi mengharapkan sukses, namun jika gagal, akan berusaha lebih keras sampai sukses. Sebaliknya, siswa yang tidak memiliki sukses dalam berprestasi akan cenderung kehilangan motivasi. Berdasarkan hasil interview dengan beberapa siswa, menyebutkan bahwa bagi siswa yang menggunakan media modul/buletin tidak membuat termotivasi, karena karakter siswa yang acuh dengan adanya perlakuan dari guru, tidak percaya diri dengan adanya siswa lain yang memiliki kemampuan lebih baik, serta malu bertanya dengan satu kelompok.

Ada interaksi antara pembelajaran Fisika dengan pendekatan Problem Based Learning (PBL) menggunakan modul dan buletin dengan kemampuan verbal siswa kategori tinggi dan rendah terhadap prestasi kognitif produk, namun tidak ada interkasi terhadap prestasi kogntif proses dan afektif siswa. Menurut Gagne dalam Winkel (1996: 323), menyebutkan bahwa untuk menumbuhkan kemampuan verbal dalam diri siswa, siswa harus memiliki ketajaman berpikir dalam menemukan konsep-konsep. Hal ini sesuai dengan pernyataan Taufiq Amir (2010: 27) tentang manfaat PBL, yaitu mendorong untuk berpikir. Meninjau dua pernyataan tersebut, dapat diketahui bahwa terdapat interaksi antara PBL dengan kemampuan verbal. Berdasarkan Hasil Uji Lanjut dengan MannWhitney $U$ menghasilkan bahwa media modul dan buletin memiliki interaksi lebih baik dengan kemampuan verbal kategori tinggi atau rendah daripada pendekatan konvensional.

Ada interaksi antara pembelajaran Fisika dengan pendekatan Problem Based Learning (PBL) menggunakan modul dan buletin dengan motivasi berprestasi siswa kategori tinggi dan rendah terhadap prestasi belajar. Menurut Barila dalam Rachel Mamlok dan Naaman (2011) menyatakan bahwa motiviasi adalah variabel yang penting dalam mendorong kinerja keterampilan serta membangun pemahaman konsep yang bermakna. Dilanjutkan oleh Taufiq Amir (2010: 27) menyatakan manfaat dari PBL yaitu dapat memotivasi pembelajar dalam 
pembelajaran. Sehingga terdapat interaksi antara PBL dengan motivasi berprestasi siswa. Berdasarkan uji lanjut menghasilkan bahwa media modul dan buletin memiliki interaksi yang lebih baik dengan motivasi berprestasi kategori tinggi atau rendah daripada pendekatan konvensional.

Tidak ada interaksi antara kemampuan verbal dan motivasi berprestasi kategori tinggi dan rendah terhadap prestasi kognitif produk, dan ada interaksi terhadap prestasi kognitif proses dan afektif. Menurut Gagne dalam Winkel (1996: 323) menjelaskan bahwa untuk menumbuhkan kemampuan verbal dalam diri siswa, harus memiliki motivasi yang tinggi sehingga informasi yang didapatkan tidak hanya disimpan dalam memori jangka pendek, tetapi dalam memori jangka panjang sehingga akan mendapatkan pembelajaran yang bermakna. Namun, dari hasil interview, sebagian siswa dalam menyerap materi masih disimpan dalam memori jangka pendek yaitu berupa hafalan, sehingga ketika mengerjakan latihan soal dan ulangan harian, siswa masih banyak yang mengalami kesulitan dalam menyelesaikan soal yang diberikan.

Ada interaksi PBL menggunakan media pembelajaran dengan kemampuan verbal dan motivasi berprestasi kategori tinggi dan rendah terhadap prestasi belajar. Menurut Taufiq Amir (2010: 27) menjelaskan manfaat yang diperoleh dari proses PBL adalah: (1) menjadi lebih ingat dan meningkatkan pemahaman isi pelajaran; (2) meningkatkan fokus pada pengetahuan yang relevan; (3) mendorong untuk berpikir; (4) membangun kerja tim, kepemimpinan, dan keterampilan sosial; (5) membangun kecakapan belajar; (6) memotivasi pembelajar. Sedangkan menurut Gagne dalam Winkel (1996: 323) menyebutkan bahwa dalam menumbuhkan kemampuan verbal dalam diri siswa, siswa harus memiliki motivasi berprestasi dan memiliki ketajaman berpikir dalam menemukan konsepkonsep sehingga pembelajaran akan lebih bermakna. Dari pernyataan tersebut, dapat diketahui bahwa ada interkasi antara PBL dengan kemampuan verbal dan motivasi berprestasi siswa. Berdasarkan uji lanjut menghasilkan bahwa pendekatan PBL menggunakan modul dan buletin memiliki interkasi yang lebih baik dengan kemampuan verbal dan motivasi berprestasi kategori tinggi dan rendah daripada pendekatan konvensional.

\section{Kesimpulan dan Rekomendasi}

Hasil penelitian dapat disimpulkan bahwa: (1) pendekatan PBL menggunakan modul dan buletin memiliki pengaruh lebih baik daripada pendekatan konvensional dalam prestasi produk dan proses; (2) tidak ada pengaruh antara pendekatan PBL menggunakan modul dan buletin dengan kemampuan verbal terhadap prestasi belajar; (3) ada pengaruh pendekatan PBL menggunakan modul dan buletin dengan motivasi berprestasi terhadap prestasi kognitif proses dan afektif; (4) pendekatan PBL menggunakan modul dan buletin memiliki interaksi yang lebih baik dengan kemampuan verbal dan motivasi berprestasi kategori tinggi dan rendah daripada pendekatan konvensional.

Rekomendasi untuk penelitian selanjutnya adalah dapat mengembangkan jenis pendekatan, metode, dan media dalam pembelajaran fisika yang lain, seperti pendekatan POE, CTL, inkuiri, video, web, dan flash. Peninjauan faktor internal siswa dapat dikembangkan dengan meninjau sikap ilmiah, kemampuan berpikir kritis, kemampuan matematis, kemampuan menggunakan alat ukur, dan kreativitas. Prestasi belajar yang diharapkan dapat mengukur ketiga aspek, yaitu aspek kognitif, afektif, dan psikomotorik. Pemberian buletin dapat diberikan kepada siswa sebelum materi dimulai, agar siswa yang diberikan modul atau buletin dalam posisi yang sama, yaitu mendapatkan media yang memuat materi secara menyeluruh sebelum pembelajaran dimulai.

\section{Daftar Pustaka}

Jane Oakhill, dkk. (2011). The Differential Relations Between Verbal, Numerical and Spatial Working Memory Abilities and Children's Reading Comprehension. International Electronic Journal of Elementary Education. 4 (1), 83-106. 
ISSN: 2252-7893, Vol 2, No 22013 (hal 114-120)

http://jurnal.fkip.uns.ac.id/index.php/sains

John D. Pantis. (2009). Planning Educational Activities and Teaching Strategies On Constructing a Conservation Educational Module. International Journal of Environmental and Science Education. 4 (4): 351-364.

Meilani Kasim. (2009). Masalah Pendidikan di Indonesia.

http://meilanikasim.wordpress.com/2009/03/08/m akalah-masalah-pendidikan-di-indonesia/. $\quad$ Di unduh tanggal 11 Mei 2012 pukul 08.11 WIB.

Rachel Mamlok dan Naaman. (2011). How Can Motivate High School Students to Study Science?. Science Educational International. 22 (1), 5-17.

Ratna Wilis Dahar. (1989). Teori-Teori Belajar. Jakarta: Erlangga.

Taufiq Amir. (2010). Inovasi Pendidikan Melalui Problem Based Learning. Jakarta: Kencana.

Undang-Undang Republik Indonesia Nomor 20 (2003). Sisdiknas dan Peraturan Pemerintah Nomor 47 Tahun 2008 tentang Wajib Belajar. Bandung: Citra Umbara.

Wasty Soemanto. (2003). Psikologi Pendidikan. Jakarta: Rineka Cipta.

Winkel. (1996). Psikologi Pengajaran. Jakarta. Gramedia Widiasarana Indonesia. 